\title{
FATTY ACIDS PROFILE AND ANTIOXIDANT ACTIVITY OF ALMOND OILS OBTAINED FROM SIX ROMANIAN VARIETIES
}

\author{
ADRIANA CECILIA CSAKVARI ${ }^{1 *}$, ANDREEA LUPITU ${ }^{2}$, SIMONA BUNGĂU ${ }^{3}$, MANUEL \\ ALEXANDRU GÎTEA ${ }^{4 \#}$, DANIELA GÎTEA ${ }^{3 \#}$, DELIA MIRELA ŢIŢ ${ }^{3}$, LUCIAN COPOLOVICI $^{2}$, \\ SEBASTIAN NEMETH $^{3 *}$, DANA COPOLOVICI ${ }^{2}$ \\ ${ }^{1}$ University of Oradea, Doctoral School of Biomedical Sciences, 1 Universității Street, 410087, Oradea, Romania \\ 2 "Aurel Vlaicu" University of Arad, Faculty of Food Engineering, Tourism and Environmental Protection, 77 Revoluţiei \\ Boulevard, Arad, Romania; Institute for Research, Development and Innovation in Technical and Natural Sciences, \\ Romania, 2 Elena Drăgoi Street, Arad, 310330, Romania \\ ${ }^{3}$ University of Oradea, Faculty of Medicine and Pharmacy, 29 Nicolae Jiga Street, 410028, Oradea, Romania \\ ${ }^{4}$ University of Oradea, Faculty of Environmental Protection, 26 Gen. Gh. Magheru Boulevard, 410048, Oradea, Romania
}

*corresponding author: sebinemeth@yahoo.com

\#Authors with equal contribution

Manuscript received: May 2018

\begin{abstract}
The almond nuts are an important source of unsaturated fats that may contribute to a significant decreasing of cholesterol level in blood. Six patented almond varieties grown in North-Western part of Romania, Bihor County (Sort A, Sort B, Sort C, Sort D, Sort E, and Sort F) were selected in order to determine the fatty acid composition and the antioxidant capacity of the oils obtained from almonds. Four fatty acids (stearic, palmitic, oleic and linoleic) were determined through their methylated derivatives by using gas-chromatography coupled with mass spectrometry. The major fatty acid was found to be the oleic acid, with the percentage varying from $61 \%$ (Sort C) to $77 \%$ (Sort D), followed by linoleic acid (19\% for Sort A variety and $28 \%$ for Sort F). Linoleic acid content was negatively correlated with oleic acid content $(r=-0.862)$ and low correlations have been found between the oleic acid and stearic acid. The antioxidant capacity determined by using DPPH method ranged values between $73 \%$ (Sort F) and $91 \%$ (Sort A) for the investigated samples. The study is important as it investigates the fatty acid profile and the antioxidant activity of almond nuts that are recommended in the human diet.
\end{abstract}

\section{Rezumat}

Migdalele sunt o sursă importantă de grăsimi nesaturate care pot contribui la scăderea semnificativă a nivelului colesterolului în sânge. Șase soiuri de migdali brevetate, cultivate în partea de nord-vest a României, (Soiul A, Soiul B, Soiul C, Soiul D, Soiul E și Soiul F) au fost selectate pentru a determina compoziția de acizi graşi și capacitatea antioxidantă a uleiurilor obţinute din migdale. Patru acizi graşi (stearic, palmitic, oleic și linoleic) au fost determinați prin derivații metilici, utilizând cromatografia de gaze cuplată cu spectrometria de masă. Acidul gras predominant a fost acidul oleic, procentul variind de la $61 \%$ (Soiul C) la 77\% (Soiul D), urmat de acidul linoleic (19\% pentru Soiul A și 28\% pentru Soiul F). Conținutul de acid linoleic a fost corelat negativ cu conținutul de acid oleic $(r=-0,862)$ și au fost găsite corelații scăzute între acidul oleic și acidul stearic. Capacitatea antioxidantă determinată prin utilizarea metodei DPPH are valori între 73\% (Soiul F) şi $91 \%$ (Soiul A), pentru probele investigate. Studiul este important, deoarece investighează profilul de acizi grași și activitatea antioxidantă a migdalelor care sunt recomandate în dieta umană.

Keywords: fatty acids, almonds, antioxidant activity

\section{Introduction}

Almond (Prunus dulcis syn. amygdalus) has an important economic value being one of the most cultivated nut trees worldwide. The total production of almond with shell exceeds 3.2 million tons in 2016 from which United States provided $63 \%$ of the total. In Europe, almost all almonds are produced in Spain [22]. In Romania, Prunus dulcis is less cultivated due to its low resistance to extreme temperatures. There are only few Romanian varieties, most of them cultivated in Eastern and Western parts of the country where the climate conditions and soil properties [24, 25] are optimal for them. The cold pressed almond oil is one of the most expensive oils used for pastry, cosmetics and pharmaceutical products. The impact of the almond seeds on human health has been presented in many papers. Due to their high content in monosaturated fatty acid, particularly oleic acid and low content of saturated fats [16, 26], almond seeds could contribute to lowering the cholesterol level [12] and decrease the risk of cardiovascular diseases $[1,8,10]$. It has been shown that almond consumption would alter the serum fatty acids profile for hyperlipidaemia individuals when they use a diet that incorporates almond [20]. Furthermore, 
consumption of nuts is essential to decrease aortic atherosclerosis in female apoE-deficient mice compared with consumption of a palm oil diet [28]. Moreover, it has been shown that almond oil consumption could decrease triglyceride level and improve lipid profiles in type 2 diabetic patients [14]. In contrast, dietary supplementation with a functional almondbased beverage did not improve performance neither for senior nor for young athletes [5].

Regarding the chemical composition, almond seeds contain different polyphenols (para-coumaric acid, caffeic acid, vanillic acid, quercetin, kaempferol, isorhamnetin) - with important antioxidant properties [8, 10, 18, 19, 21-23], and vitamin B2 and B3 [2]. In general, fatty acids profiles of almond oil have shown high percentages of monounsaturated fatty acids and low content of unsaturated fatty acids [35]. Anyway, the composition of oils depends on origin, country and climatic conditions and even vary between different genotypes [13, 18, 19, 21, 22, 34]. Sathe et $a l$. have shown that the most abundant fatty acids in almonds grown in California are oleic and linoleic acids, but the quantity depends on the location and the crop year [26]. The same results have been found for different almond varieties grown in Spain [16]. Furthermore, significant differences have been determined for the fatty acid profile depending on the pollination treatment [16].

The aim of the present study is to examine the fatty acids composition of six different almond oils varieties from Romania and to show their unique antioxidant capacities.

\section{Materials and Methods}

Chemicals

The commercial chemicals and solvents used in the study are reagent grade and were used without further purification. Acetone was purchased from Merck, Germany. All solvents used for chromatographic determination were of gas-chromatography purity and have been purchased from Sigma-Aldrich, Germany. Sample collection

Six almond varieties (patented by Gîtea M. A. et al.), noted as Sort A [29], Sort B [9], Sort C [30], Sort D [31], Sort E [32] and Sort F [33] were grown in an orchard, located in North-Western Romania [10].

Preparation of almond seed oils

The almond seeds were collected during AugustSeptember period, 2017, dehulled and sorted to remove all mesocarp. The seeds were sundried for several days and then finely ground into flour using a blending machine. $100 \mathrm{~g}$ of the prepared almond sample flour and $300 \mathrm{~mL}$ petroleum ether were subjected to a Soxhlet extraction for 4 hours.

Determination of fatty acid concentration

The fatty acids were chromatographed as methyl esters according to a modified protocol of the method described by Copolovici et al. [8]. Briefly, $0.3 \mathrm{~mL}$ of oil samples and $0.6 \mathrm{~mL}$ of methanol/toluene/sulphuric acid $(88 / 10 / 2, \mathrm{v} / \mathrm{v} / \mathrm{v})$ were pipetted into Eppendorf tubes, vortexed and then kept at $80^{\circ} \mathrm{C}$ for $1 \mathrm{~h}$. The resulting methyl esters were extracted twice with $0.5 \mathrm{~mL}$ of heptane and analysed by GC-MS in a Shimadzu 2010 Plus gas chromatography equipment (Shimadzu, Kyoto, Japan). A DB 1 capillary column (30 m length, $0.25 \mathrm{~mm}$ i.d., $0.25 \mu \mathrm{m}$ film thickness) with helium as the carrier gas at a flow rate of 0.93 $\mathrm{L} / \mathrm{min}$ have been used. The injector temperature and MS source were maintained at a temperature of $250^{\circ} \mathrm{C}$ and $200^{\circ} \mathrm{C}$, respectively. In order to calculate the retention indexes (Kovat's indexes) we used a standard mixture of alkanes (C7-C40) Supelco, USA. Identification of different fatty acid methyl esters has been done based on their MS spectra using NIST 14 library and Willy 09 library.

Antioxidant activity

The in vitro antioxidant activity of almond oils obtained from the six genotypes investigated was determined by using the DPPH (1,1-diphenyl-2-picrylhydrazyl) free radical scavenging activity, a spectrophotometric method depicted by Tuberoso et al. (2007) [36]. The data are expressed as Trolox equivalent antioxidant capacity (TEAC, mg/L), by using a Trolox calibration curve. $20 \mu \mathrm{L}$ of sample was added to $3 \mathrm{~mL}$ of methanolic DPPH $(0.2 \mathrm{mM})$. The spectrophotometric measurements were performed after a 1-hour period of incubation, in the dark, at room temperature, with a ScanDrop 200 nano-volume spectrophotometer (Analytic Jena, Germany) at $517 \mathrm{~nm}$, using a $10 \mathrm{~mm}$ cuvette. Positive controls containing $0.2 \mathrm{mM}$ DPPH solution were used as reference. Inhibition of the DPPH stable free radical was calculated with eq. (1):

$$
\% \text { Inhibition }=\frac{A b s_{\text {control }}-A b s_{\text {sample }}}{A b s_{\text {control }}} \times 100
$$

where $\mathrm{Abs}_{\text {control }}$ is the absorbance of $0.2 \mathrm{mM} \mathrm{DPPH}$ in ethanol and $\mathrm{Abs}_{\text {sample }}$ is the absorbance of $0.2 \mathrm{mM}$ DPPH in extract.

The Trolox calibration curve in methanol, in the range $0.02-4.00 \mathrm{mM}$ was also attained, and data were calculated in Trolox equivalent antioxidant capacity (TEAC, mg/L). The Flash Soft Pro software was used to make the analysis. All measurements have been performed in triplicates.

\section{Results and Discussion}

Fatty acids profile

Diverse oils present different quantities of common fatty acids. Therefore, the chromatographic determination of the fatty acids contained in oils is crucial to determine the quality and possible alteration of the oil sample. In the gas chromatographic analysis of the almond oils investigated in the present study, palmitic acid (16:0), stearic acid (18:0), oleic acid 
FARMACIA, 2019, Vol. 67, 5

(18:1), and linoleic acid (18:2) were determined. They have been shown the average concentrations as follows: palmitic acid $7.04 \%$, stearic acid $2.28 \%$, oleic acid $67.34 \%$, and linoleic acid $23.87 \%$, as it is depicted in Table I.

Table I

Fatty acids profile (in \%) and retention indexes for almond oils obtained from six Romanian varieties

\begin{tabular}{|c|c|c|c|c|c|c|}
\hline $\begin{array}{l}\text { Almond } \\
\text { variety }\end{array}$ & $\begin{array}{c}\text { Palmitic ac. } \\
\mathrm{C}_{16: 0}\end{array}$ & $\begin{array}{c}\text { Stearic ac. } \\
\mathrm{C}_{18: 0}\end{array}$ & $\sum$ SFA $(\%)$ & $\begin{array}{l}\text { Oleic ac. } \\
\mathrm{C}_{18: 1 n g} 9\end{array}$ & $\begin{array}{c}\text { Linoleic ac. } \omega-6 \text {, } \\
C_{18: 2 n} \quad 9,12\end{array}$ & $\begin{array}{l}\text { Ratio of oleic ac. } \\
\text { to linoleic ac. }\end{array}$ \\
\hline $\mathbf{R I}^{*}$ & 2006 & 2217 & - & 2192 & 2183 & - \\
\hline Sort A [29] & $6.50 \pm 0.79$ & $2.91 \pm 0.69$ & $11.59 \pm 1.96$ & $69.02 \pm 1.68$ & $19.39 \pm 2.34$ & 3.56 \\
\hline Sort B [9] & $5.65 \pm 0.62$ & $2.52 \pm 0.31$ & $8.17 \pm 0.93$ & $70.82 \pm 3.97$ & $21.02 \pm 3.66$ & 3.37 \\
\hline Sort C [30] & $10.78 \pm 4.33$ & $2.83 \pm 0.07$ & $13.61 \pm 4.41$ & $70.82 \pm 3.97$ & $26.47 \pm 4.35$ & 2.32 \\
\hline Sort D [31] & $4.44 \pm 0.51$ & ND & $4.44 \pm 0.51$ & $77.27 \pm 4.19$ & $19.77 \pm 1.87$ & 3.91 \\
\hline Sort E [32] & $6.8 \pm 0.62$ & $2.06 \pm 0.07$ & $8.86 \pm 0.69$ & $64.26 \pm 1.08$ & $27.89 \pm 1.03$ & 2.30 \\
\hline Sort F [33] & $8.22 \pm 1.85$ & $3.36 \pm 0.36$ & $11.57 \pm 2.21$ & $61.34 \pm 1.60$ & $28.66 \pm 1.63$ & 2.14 \\
\hline $\begin{array}{l}\text { General } \\
\text { average }\end{array}$ & 7.06 & 2.28 & 9.70 & 67.34 & 23.87 & 2.93 \\
\hline
\end{tabular}

*RI: retention index (Kovat's index); ND: Not determined

In Sort D [31], stearic acid was not determined. In the analysed samples, saturated fatty acids (SFA) $9.70 \%$, unsaturated fatty acids (USFA) $91.21 \%$ and a rate of USFA/SFA of 9.40 , monounsaturated fatty acids (MUFA) 67.34\%, polyunsaturated fatty acids (PUFA) $23.87 \%$ and a MUFA/PUFA ratio of 2.82 were found. As it can be observed, the highest

concentration in any fatty acid in almond oil is oleic acid, a MUFA important in human consumption.

In order to compare the fatty acid composition of almond oils obtained from different almond varieties grown in diverse parts of the world we used the data obtained in this study and that was reported in some papers $[4,6,13,15,17,26,27,34]$. These data are shown in Table II.

Table II

The average sum values of different fatty acids classes: SFA, MUFA and PUFA, in \%, determined in the present study and some data reported in literature

\begin{tabular}{|c|c|c|c|c|}
\hline \multirow{2}{*}{$\begin{array}{c}\text { Country } \\
\text { of study }\end{array}$} & Reference & \multicolumn{3}{|c|}{ Fatty acids classes } \\
\cline { 3 - 5 } & No. & $\sum$ SFA & $\sum$ MUFA & $\sum$ PUFA \\
\hline Present study, Romania & - & 9.70 & 67.34 & 23.87 \\
\hline China & 27 & 8.89 & 66.06 & 24.40 \\
\hline Turkey & 3 & 9.33 & 70.84 & 18.48 \\
\hline Turkey & 10 & 6.19 & 74.46 & 17.89 \\
\hline Spain & 24 & 8.5 & 62.5 & 29.0 \\
\hline Spain & 5 & 8.38 & 66.06 & 25.62 \\
\hline Spain & 14 & 8.31 & 70.93 & 19.65 \\
\hline Spain & 13 & 8.15 & 71.85 & 18.64 \\
\hline USA & 23 & 6.69 & 65.51 & 27.27 \\
\hline
\end{tabular}

Tian et al. determined 18 fatty acids, from (14:0) till (23:0), in 13 varieties of almond oils, from which 13 fatty acids presented a concentration smaller than $1 \%$ [35]. The major percentage was determined as oleic acid (64.78\%), followed by linoleic acid $(22.71 \%)$. The total amounts of fatty $8.89 \%$, as it is acids were MUFA $66.06 \%$, PUFA, $24.40 \%$ and SFA, depicted in Table II.

Askin et al. have selected 26 genotypes from almond population grown in Turkey, with the kernel weight of the genotypes ranging from 0.50 to $1.34 \mathrm{~g}$ [4]. For the almond oils investigated the fatty acids content varied as follows: oleic acid: $50.41 \%$ and $81.2 \%$, linoleic acid: $6.21 \%$ to $37.13 \%$, palmitic acid: $5.46 \%$ and $15.78 \%$, stearic acid: $0.80 \%$ and $3.83 \%$, palmitoleic acid: $0.36 \%$ and $2.52 \%$. The study revealed that the almond genotypes with high kernel weight presented higher contents of oleic, stearic, and palmitic acids, but lower contents of linoleic acid, meanwhile the shell thickness was positively correlated with the oleic acid content and negatively correlated with SFA content.

Soler et al. determined the fatty acid composition of Pons almond variety seeds depending on harvesting in three different development stages, and these contained an average of: $6.5 \%$ palmitic acid, $1.5 \%$ stearic acid, $0.5 \%$ palmitoleic acid, $62.5 \%$ oleic acid and $29.0 \%$ linoleic acid [27].

Data obtained from the investigation of fatty acid profile of 19 almond varieties [5] were also reported. In this study was also revealed that two unsaturated acids (18:1 and 18:2) represent more than $90 \%$ of the total fatty acids. 
FARMACIA, 2019, Vol. 67, 5

Kodad et al. reported detailed analyses of fatty acid composition and tocopherol concentration for 44 local varieties of almonds from Spain in three different years of harvesting [16]. The study showed values between $64 \%$ and $80 \%$ of the concentration of oleic acid (the main acid) in the samples, and oleic acid/ linoleic acid ratio varying from 2.8 to 5.5 . The results demonstrated that the chemical composition of almond oils depends on the phenotypic variability, even grown in similar climate conditions and the diversity of germplasm collections must be kept.

Figure 1a presents the correlation between the percentage of linoleic and oleic acids content in almond oils determined in our study and in articles mentioned in Table II, and Figure $1 \mathrm{~b}$ shows the correlation between stearic and oleic acids in almond oils investigated in the present study.
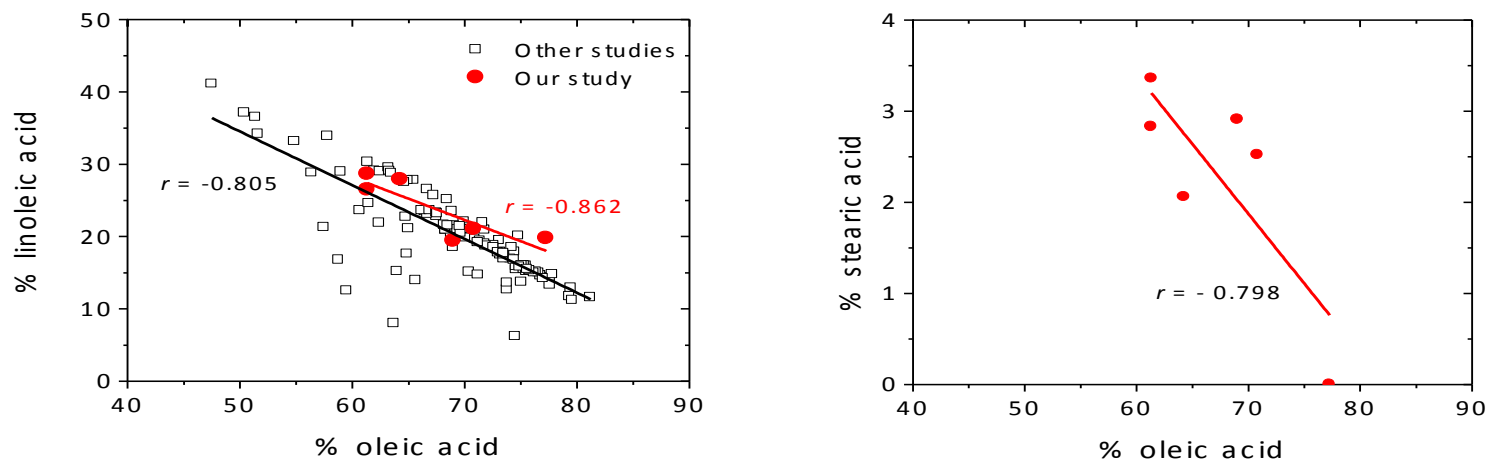

Figure 1.

Correlation between the percentage of $\mathbf{a}$. linoleic and oleic acids content in almond oils and $\mathbf{b}$. stearic and oleic acids in almond oils

Furthermore, we evaluated the correlation analyses for the Romanian almond varieties analysed in our study. We determined that linoleic acid content was negatively correlated with oleic acid content, the highest correlation coefficient being $\mathrm{r}=-0.862$. The meta-correlation analyses for 108 different almond oils from different countries and varieties discussed above indicate the same trend, with a correlation coefficient of $r=-0.805$. On the other hand, low correlations have been found between the oleic acid and stearic acid $(r=-0.798)$. Similarly, a negative correlation has been found for almond genotypes from Anatolia, Turkey [4].

The ratio of oleic acid to linoleic acid is an important parameter to evaluate kernel quality, and the values obtained for our samples are between 2.14 (Sort F [33]) and 3.91 (Sort D [31]), with an average of 2.39 (Table I). The high content of oleic acid is assuring a good resistance of almond nuts for diverse processes as industrial processing, storage, transportation [16].

\section{DPPH radical scavenging activity}

The DPPH radical scavenging activity was determined by using a spectrophotometric method [36]. The $\mathrm{DPPH} \cdot$ radical, which is a stable organic free radical, presents an absorption maximum band at $\lambda=515$ $528 \mathrm{~nm}$ and it is widely used to assess the scavenging ability of an antioxidant. During the reactions of the DPPH with antioxidant molecules the blue colour of the DPPH solution may reach to a yellow-coloured solution, in accordance with the hydrogen donating ability of the antioxidants. The DPPH - free radical scavenging activities of almond seeds oil of the six Romanian varieties were evaluated. Inhibition values determined for the studied oils varied from $73.13 \%$ for sort F till 91.21\% for Sort A [29].

Similarly, in Table III are presented the values of TEAC, $\mathrm{mg} / \mathrm{L}$, for the investigated samples, Sort A [29] exhibiting the highest antioxidant activity.

Table III

Antioxidant activity of the oils obtained from six new almond varieties grown in the North-Western part of Romania

\begin{tabular}{|c|c|c|}
\hline Almond variety & Inhibition \% & TEAC (mg/L) \\
\hline Sort A [29] & $91.2 \pm 2.3$ & $1.54 \pm 0.02$ \\
\hline Sort B [9] & $85.4 \pm 1.6$ & $1.48 \pm 0.02$ \\
\hline Sort C [30] & $89.2 \pm 1.7$ & $1.52 \pm 0.02$ \\
\hline Sort D [31] & $76.2 \pm 1.6$ & $1.38 \pm 0.01$ \\
\hline Sort E [32] & $79.5 \pm 5.8$ & $1.42 \pm 0.06$ \\
\hline Sort F [33] & $73.1 \pm 1.4$ & $1.35 \pm 0.02$ \\
\hline
\end{tabular}

Our study presents similar results as that reported by Keser et al. which determined that almond extract scavenged $89.50 \%$ of the ABTS radical, $66.77 \%$ of the hydroxyl radical, and $87.30 \%$ of the DPPH 
FARMACIA, 2019, Vol. 67, 5

radical [15]. In their study, the major fatty acids were oleic $(76.23 \%)$ and linoleic acid $(15.43 \%)$ with a ratio of them around 3.5 . It could be speculated that such ratio of oleic acid to linoleic acid is responsible for high antioxidant activities and lower rancidity. Indeed, it has been shown that white apricot almond oil presented a higher scavenging capacity compared with that of ascorbic acid in the DPPH system [35].

Arranz et al. determined the antioxidant activity of several nut oils and obtained the following ranking: peanut oil $<$ almond oil $<$ walnut oil $<$ hazelnut oil $<$ pistachio oil (with $\mathrm{EC}_{50} 712.2 \pm 36 \mathrm{~g}$ oil $/ \mathrm{g}$ DPPH for almond oil) [3]. These results are well corroborated with our earlier published data related to antioxidant activity of walnut cold-pressed oil [8], That contained $8.80 \%$ SFA, $18.36 \%$ MUFA and $72.84 \%$ PUFA.

\section{Conclusions}

The fatty acid composition and antioxidant capacity were determined for six patented almond varieties grown in the North-Western part of Romania, Bihor County. The main fatty acid is oleic acid, with the percentage varying from $61 \%$ to $77 \%$, followed by linoleic acid (19-28\%). Linoleic acid content was negatively correlated with oleic acid content, the highest correlation coefficient being $r=-0.862$ and low correlations have been found between oleic and stearic acids $(r=-0.798)$. The inhibition percentage determined by using DPPH system varied between $73 \%$ and $91 \%$ for the investigated samples. This study indicates, once again, the importance of nuts in the human diet, including almond kernels that are rich in MUFA and present a significant antioxidant activity.

\section{Acknowledgement}

Funding for the equipment used in the study has been provided by the European Commission and the Romanian Government (project POSCCE 621/2014).

\section{References}

1. Abdel-Daim MM, Zakhary NI, Aleya L, Bungău SG, Bohara RA, Siddiqi NJ, Aging, Metabolic, and Degenerative Disorders: Biomedical Value of Antioxidants. Oxid Med Cell Longev., 2018; 2018: 1-2.

2. Amarowicz R, Troszynska A, Shahidi F, Antioxidant activity of almond seed extract and its fractions. $J$ Food Lipids, 2005; 12(4): 344-358.

3. Arranz S, Cert R, Perez-Jimenez J, Cert A, SauraCalixto F, Comparison between free radical scavenging capacity and oxidative stability of nut oils. Food Chem., 2008; 110(4): 985-990.

4. Askin MA, Balta MF, Tekintas FE, Kazankaya A, Balta F, Fatty acid composition affected by kernel weight in almond Prunus dulcis (Mill.) D.A. Webb. genetic resources. J Food Compost Anal., 2007; 20(1): 7-12.
5. Capo X, Martorell M, Sureda A, Riera J, Drobnic F, Tur JA, Pons A, Effects of almond- and olive oil-based docosahexaenoic- and vitamin e-enriched beverage dietary supplementation on inflammation associated to exercise and age. Nutrients, 2016; 8(10): 1-18.

6. Carratala MLM, Garcia-Lopez C, Berenguer-Navarro $\mathrm{V}$, Grane-Teruel N, New contribution to the chemometric characterization of almond cultivars on the basis of their fatty acid profiles. J Agric Food Chem., 1998; 46(3): 963-967.

7. Copolovici D, Bungău S, Boscencu R, Ţiţ DM, Copolovici L, The fatty acids composition and antioxidant activity of walnut cold press oil. Rev Chim (Bucharest), 2017; 68(3): 507-509.

8. de Souza RGM, Schincaglia RM, Pimentel GD, Mota JF, Nuts and human health outcomes: A Systematic Review. Nutrients, 2017; 9(12): 1-23.

9. Domuța C, Bara L, Bara C, Laslo V, Clitan I, Șcheau V, National Patent Number: 00162/ 30.12.2008.

10. Fodor K, Țiţ DM, Paşca B, Buştea C, Uivaroşan D, Endres L, Iovan C, Abdel-Daim M, Bungău S, Longterm resveratrol supplementation as a secondary prophylaxis for stroke. Oxid Med Cell Longev., 2018; 2018: 1-10.

11. Gîtea $\mathrm{M}$, The analysis of almond cultivars grown in northwestern Romania. Nat Resources Sustain Develop., 2013; 3: 131-136.

12. Hamasaki H, Hamasaki Y, Nuts for physical health and fitness: A review. AIMS Med Sci., 2017; 4(4): 441-455.

13. Karatay H, Sahin A, Yilmaz O, Aslan A, Major fatty acids composition of 32 almond (Prunus dulcis Mill. D.A. Webb) genotypes distributed in east and southeast of Anatolia. Turk J Biochem., 2014; 39(3): 307-316.

14. Kaseb F, Rashidi M, Afkhami-Ardekani M, Fallahzadeh $\mathrm{H}$, Effect of olive, almond and walnut oil on cardiovascular risk factors in type 2 diabetic patients. Int J Diabetes Dev Ctries., 2013; 33(2): 115-119.

15. Keser S, Demir E, Yilmaz O, Phytochemicals and antioxidant activity of the almond kernel (Prunus dulcis Mill.) from Turkey. J Chem Soc Pak., 2014; 36(3): 534-541.

16. Kodad O, Estopanan G, Juan T, Alonso JM, Espiau MT, Company RSI, Oil content, fatty acid composition and tocopherol concentration in the Spanish almond genebank collection. Sci Hortic., 2014; 177: 99-107.

17. Kodad O, Estopanan G, Juan T, Company RSI, Xenia Effects on oil content and fatty acid and tocopherol concentrations in autogamous almond cultivars. J Agric Food Chem., 2009; 57(22): 1080910813.

18. Moisa C, Copolovici L, Bungău S, Pop G, Imbrea I, Lupitu A, Nemeth S, Copolovici D, Wastes resulting from aromatic plants distillation - bio-sources of antioxidants and phenolic compounds with biological active principles. Farmacia, 2018; 66(2): 289-295.

19. Moşteanu D, Bârsan G, Otrisal P, Giurgiu L, Oancea $\mathrm{R}$, Obtaining the volatile oils from wormwood and tarragon plants by a new microwave hydrodistillation method. Rev Chim (Bucharest), 2017; 68(11): 24992502 . 
20. Nishi S, Kendall CWC, Gascoyne AM, Bazinet RP, Bashyam B, Lapsley KG, Augustin LSA, Sievenpiper JL, Jenkins DJA, Effect of almond consumption on the serum fatty acid profile: a dose-response study. Brit J Nutr., 2014; 112(7): 1137-1146.

21. Pallag A, Bungău SG, Ţiţ DM, Jurca T, Sîrbu V, Honiges A, Horhogea C, Comparative study of polyphenols, flavonoids, and chlorophylls in Equisetum arvense T. populations. Rev Chim (Bucharest), 2016; 67(3): 530-533.

22. Rabadan A, Alvarez-Orti M, Gomez R, Pardo-Gimenez A, Pardo JE, Suitability of Spanish almond cultivars for the industrial production of almond oil and defatted flour. Sci Hortic., 2017; 225: 539-546.

23. Rugina D, Vicaş S, Momeu C, Socaciu C, Antioxidant activity of flavanols from grape seed extracts. Chemické Listy, 2008; 99:1234-35

24. Samuel A, Brejea R, Domuţa C, Bungău S, Cenuşa N, Țiţ DM, Enzymatic indicators of soil quality. $J$ Environ Prot Ecol., 2017; 189(3): 1425-1433.

25. Samuel AD, Tiţ̧ DM, Melinte (Frunzulică) CE, Iovan C, Purza L, Gîtea M, Bungău S, Enzymological and physicochemical evaluation of the effects of soil management practices. Rev Chim (Bucharest), 2017; 68(10): 2243-2247.

26. Sathe SK, Seeram NP, Kshirsagar HH, Heber D, Lapsley KA, Fatty acid composition of California grown almonds. J Food Sci., 2008; 73(9): C607C614.

27. Soler L, Canellas J, Sauracalixto F, Oil content and fatty-acid composition of developing almond seeds. J Agric Food Chem., 1988; 36(4): 695-697.
28. Surra JC, Barranquero C, Torcal MP, Orman I, Segovia JC, Guillen N, Navarro MA, Arnal C, Osada J, In comparison with palm oil, dietary nut supplementation delays the progression of atherosclerotic lesions in female apoE-deficient mice. Brit J Nutr., 2013; 109(2): 202-209.

29. Șcheau V, Șcheau AM, Gîtea M, Domuța CG, Brejea $R$, Bara C, Vlad M, National Patent Number: 00299/20.03.2013.

30. Șcheau V, Șcheau AM, Gîtea M, Domuța CG, Domuța C, Brejea R, Vlad M, National Patent Number: 00301/20.03.2013.

31. Scheau V, Șcheau AM, Gîtea M, Vlad M, Domuța CG, Bara L, Brejea R, National Patent Number: 00300/20.03.2013.

32. Scheau V, Gîtea M, National Patent Number: 00163/30.12.2008.

33. Șcheau V, Şcheau V, National Patent Number: 00165/30.12.2008.

34. Tășchină M, Copolovici DM, Bungău S, Lupitu AI, Copolovici I, Iovan C, The influence of residual acetaminophen on Phaseolus vulgaris L. secondary metabolites. Farmacia, 2017; 65(5): 709-713.

35. Tian HL, Zhang H, Zhan P, Tian FW, Composition and antioxidant and antimicrobial activities of white apricot almond (Amygdalus communis L.) oil. Eur J Lipid Sci Technol., 2011; 113(9): 1138-1144.

36. Tuberoso CIG, Kowalczyk A, Sarritzu E, Cabras P, Determination of antioxidant compounds and antioxidant activity in commercial oilseeds for food use. Food Chem., 2007; 103(4): 1494-1501. 